\title{
Clinical Possibilities of Manifestation of Juvenile Idiopathic Arthritis
}

\author{
Lucia Sur ${ }^{1}$, Floca Emanuela ${ }^{1}$, Sur Genel ${ }^{1,2}$, Daniel Sur ${ }^{1}$ and Samasca Gabriel ${ }^{1,2^{*}}$ \\ ${ }^{1} /$ uliu Hatieganu University of Medicine and Pharmacy, Cluj-Napoca, Romania \\ ${ }^{2}$ Emergency Clinical Hospital for Children, Cluj-Napoca, Romania
}

\section{Introduction}

Juvenile Idiopathic Arthritis is the most common rheumatologic disease in children and one of the most common chronic diseases of childhood. The term JIA encompasses a heterogeneous group of disorders that all share the clinical manifestation of chronic joint inflammation. The etiology is unknown, but both genetic and environmental factors are believed to be involved. Management of the disease has improved in recent years due to advances of pharmacologic treatment options. The prognosis of patients with juvenile idiopathic arthritis is better.

\section{Clinical}

Chronic joint inflammation must be present for at least 6 weeks in the same joint before the diagnosis of juvenile idiopathic arthritis be made. Disease onset is insidious or sudden and it is characterized by morning stiffness and arthralgia during the day. Usually children with juvenile idiopathic arthritis were absent from school and activities during physical education classes is limited reflecting disease severity. Affecting the lower extremities causing limping in children, so a morning limp that improves during the day can be found [1-3].

Arthritis can be present in many conditions. A preceding illness must bring into question the possibility of infectious trigger for post infectious arthritis. Reactive arthritis should be called into question in any child with gastroenteritis and arthritis of large joints of the lower extremities. Lyme disease caused by Borrelia burgdorferi, is a major health problem in endemic areas. Arthritis is a late manifestation of the disease. So a history of travel to endemic areas exposed to ticks raises the possibility of Lyme disease. If the patient complains of severe joint pain, diagnostic alternatives include acute rheumatic fever, acute lymphocytic leukemia, septic arthritis and osteomyelitis [4,5]. Gastrointestinal symptoms, microcytic anemia, and elevated inflammatory markers raise the possibility of inflammatory bowel disease. Weight loss in the absence of diarrhea may be observed in patients with active juvenile idiopathic arthritis. This sign can also be seen in patients with acute lymphocytic leukemia and in patients with inflammatory bowel disease. Differential diagnoses include systemic lupus erythematosus. Pericarditis with orthopnea can be observed both in juvenile idiopathic arthritis and systemic lupus erythematosus [6-8].

\section{Classification of Juvenile Idiopathic Arthritis}

Systemic Arthritis

Definition: Arthritis in one or more joints with or proceeded by fever of at least 2 weeks' duration that is documented to be daily for at least 3 days [9-12].

\section{Inclusion criteria}

\begin{tabular}{l|l} 
Exclusion criteria & Exia
\end{tabular}

2. Generalized lymph node enlargement

3. Hepatosplenomegaly

4. Serositis

1. Psoriasis or a history of psoriasis in the patient or first-degree relative

2. Arthritis in an HLA-B27 positive male beginning after the $6^{\text {th }}$ birthday

3. Ankylosing spondylitis, enthesitis related arthritis, sacroiliitis with inflammatory bowel disease, Reiter's syndrome, or acute anterior uveitis, or a history of one of these disorders in a first-degree relative

Signs and symptoms

$\checkmark$ Arthralgia

$\checkmark$ Myalgia

$\checkmark$ Chest pain and shortness of breath are signs of pericarditis or pleuritis

$\checkmark$ Muscle tenderness

\section{Oligoarthritis}

Definition: Arthritis affecting one to 4 joints during the first 6 months of disease $[9,13]$.

\begin{tabular}{|c|c|}
\hline Inclusion criteria & Exclusion criteria \\
\hline $\begin{array}{l}\text { Persistent oligoarthritis: affecting } \\
\text { not more than } 4 \text { joints throughout } \\
\text { the disease course. } \\
\text { Extended ologoarthritis: affecting a } \\
\text { total of more than } 4 \text { joints after the } \\
\text { first } 6 \text { months of disease. }\end{array}$ & $\begin{array}{l}\text { 1. Psoriasis or a history of psoriasis in the } \\
\text { patient or first-degree relative } \\
\text { 2. Arthritis in an HLA-B27 positive male } \\
\text { beginning after the } 6^{\text {th }} \text { birthday } \\
\text { 3. Ankylosing spondylitis, enthesitis related } \\
\text { arthritis, sacroiliitis with inflammatory }\end{array}$ \\
\hline $\begin{array}{l}\text { Signs and symptoms } \\
\checkmark \quad \text { Larger joints such as the knees, } \\
\text { ankles, wrists are affected } \\
\checkmark \quad \text { Limp }\end{array}$ & $\begin{array}{l}\text { bowel disease, Reiter`s syndrome, or } \\
\text { acute anterior uveitis, or a history of } \\
\text { one of these disorders in a first-degree } \\
\text { relative }\end{array}$ \\
\hline $\begin{array}{ll}\checkmark & \text { Extensor muscle atrophy } \\
\checkmark & \text { Flexion contractures in the } \\
\text { knees and the wrists }\end{array}$ & $\begin{array}{l}\text { 4. The presence of IgM rheumatoid fac- } \\
\text { tor on at least } 2 \text { occasions at least } 3 \\
\text { months apart }\end{array}$ \\
\hline$\checkmark \quad$ Anterior uveitis & $\begin{array}{l}\text { 5. The presence of systemic JIA in the } \\
\text { patient }\end{array}$ \\
\hline
\end{tabular}

\section{Polyarthritis}

Definition: Arthritis affecting 5 or more joints during the first 6 months of disease $[9,14,15]$.

\begin{tabular}{|c|c|}
\hline Inclusion criteria & \multirow{4}{*}{$\begin{array}{l}\text { Exclusion criteria } \\
\text { 1. Psoriasis or a history of psoriasis in } \\
\text { the patient or first-degree relative } \\
\text { 2. Arthritis in an HLA-B27 positive } \\
\text { male beginning after the } 6^{\text {th }} \text { birthday } \\
\text { 3. Ankylosing spondylitis, enthesitis } \\
\text { related arthritis, sacroilitis with in- } \\
\text { flammatory bowel disease, Reiter's } \\
\text { syndrome, or acute anterior uveitis, } \\
\text { or a history of one of these disor- } \\
\text { ders in a first-degree relative } \\
\text { 4. The presence of IgM rheumatoid } \\
\text { factor on at least } 2 \text { occasions at } \\
\text { least } 3 \text { months apart } \\
\text { 5. The presence of systemic JIA in the } \\
\text { patient }\end{array}$} \\
\hline $\begin{array}{l}\text { Rheumatoid factor negative: a test for } \\
\text { RF is negative. }\end{array}$ & \\
\hline Signs and symptoms & \\
\hline $\begin{array}{ll}\checkmark & \text { Both large and small joints can be } \\
& \text { affected, with symmetrical distribu- } \\
& \text { tion } \\
\checkmark & \text { Fever } \\
\checkmark & \text { Severe limitations in motion, muscle } \\
& \text { weakness, decreased physical } \\
& \text { function }\end{array}$ & \\
\hline $\begin{array}{l}\text { Rheumatoid factor positive: } 2 \text { or more } \\
\text { tests for RF at least } 3 \text { months apart } \\
\text { during the first } 6 \text { months of disease are } \\
\text { positive. }\end{array}$ & $\begin{array}{l}\text { 1. Psoriasis or a history of psoriasis in } \\
\text { the patient or first-degree relative } \\
\text { 2. Arthritis in an HLA-B27 positive } \\
\text { male beginning after the } 6^{\text {th }} \text { birthday }\end{array}$ \\
\hline \begin{tabular}{ll}
\multicolumn{2}{c}{ Signs and symptoms } \\
$\checkmark \checkmark$ & Both large and small joints can be \\
& affected, with symmetrical distribu- \\
& tion \\
$\checkmark$ & Fever \\
$\checkmark$ & Severe limitations in motion, muscle \\
& weakness, decreased physical \\
& function \\
$\checkmark$ & Rheumatoid nodules can be found
\end{tabular} & $\begin{array}{l}\text { 3. Ankylosing spondylitis, enthesitis } \\
\text { related arthritis, sacroiliitis with in- } \\
\text { flammatory bowel disease, Reiter's } \\
\text { syndrome, or acute anterior uveitis, } \\
\text { or a history of one of these disor- } \\
\text { ders in a first-degree relative } \\
\text { 4. The presence of systemic JIA in the } \\
\text { patient }\end{array}$ \\
\hline
\end{tabular}

*Corresponding author: Dr.Gabriel Samaşca, Department of Immunology, Croitorilor Street, 19-21 No,"luliu Hațieganu" University of Medicine and Pharmacy Cluj-Napoca, Romania, E-mail: Gabriel.Samasca@umfcluj.ro

Received November 28, 2012; Accepted November 29, 2012; Published December 03, 2012

Citation: Sur L, Emanuela F, Genel S, Sur D, Gabriel S (2010) Clinical Possibilities of Manifestation of Juvenile Idiopathic Arthritis. J Biomol Res Ther $\square$ : [e109. doi:10.4172/2167-7956.1000e109

Copyright: @ 2010 Sur L, et al. This is an open-access article distributed under the terms of the Creative Commons Attribution License, which permits unrestricted use, distribution, and reproduction in any medium, provided the original author and source are credited. 
Citation: Sur L, Emanuela F, Genel S, Sur D, Gabriel S (201 Ÿ) Clinical Possibilities of Manifestation of Juvenile Idiopathic Arthritis. J Biomol Res Ther [: e109. doi:10.4172/2167-7956.1000e109

Page 2 of 2

\section{Psoriatic Arthritis}

Definition: Arthritis and psoriasis, or arthritis and at least 2 of inclusion criteria $[9,16]$.

\begin{tabular}{|c|c|}
\hline Inclusion criteria & \multirow{10}{*}{$\begin{array}{l}\text { Exclusion criteria } \\
\text { 1. Arthritis in an HLA-B27 positive male } \\
\text { beginning after the 6th birthday } \\
\text { 2. Ankylosing spondylitis, enthesitis related } \\
\text { arthritis, sacroiliitis with inflammatory } \\
\text { bowel disease, Reiter's syndrome, or } \\
\text { acute anterior uveitis, or a history of one } \\
\text { of these disorders in a first-degree relative } \\
\text { 3. The presence of IgM rheumatoid factor } \\
\text { on at least } 2 \text { occasions at least } 3 \text { months } \\
\text { apart } \\
\text { 4. The presence of systemic JIA in the } \\
\text { patient }\end{array}$} \\
\hline 1. 1. Dactylitis & \\
\hline 2. 2. Nail pitting or onyc & \\
\hline $\begin{array}{l}\text { 3. } 3 \text {. Psoriasis in a first-degree } \\
\text { relative }\end{array}$ & \\
\hline Signs and symptoms & \\
\hline$\checkmark \quad$ Monoarticular arthritis & \\
\hline$\checkmark$ Tenosynovitis & \\
\hline & \\
\hline $\begin{array}{l}\checkmark \text { Disordered bone growth with } \\
\text { resultant shortening }\end{array}$ & \\
\hline & \\
\hline
\end{tabular}

\section{Enthesitis Related Arthritis}

Definition: Arthritis and enthesitis, or arthritis or enthesitis with at least 2 of inclusion criteria $[9,15,17]$.

\begin{tabular}{|c|c|}
\hline Inclusion criteria & Exclusion criteria \\
\hline 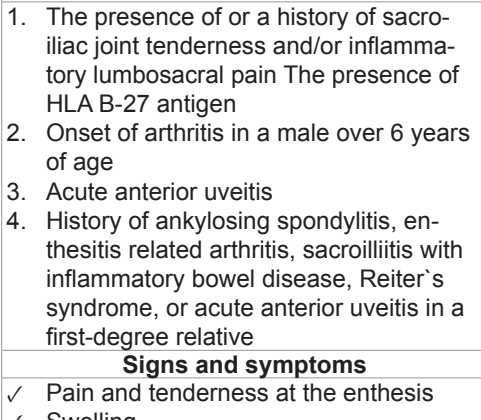 & $\begin{array}{l}\text { 1. Psoriasis or a history of psoria- } \\
\text { sis in the patient or first-degree } \\
\text { relative } \\
\text { 2. The presence of IgM rheuma- } \\
\text { toid factor on at least } 2 \text { occa- } \\
\text { sions at least } 3 \text { months apart } \\
\text { 3. The presence of systemic JIA in } \\
\text { the patient }\end{array}$ \\
\hline
\end{tabular}

\section{Undifferentiated Arthritis}

Definition: Arthritis that fulfills criteria in no category or in 2 or more of the above categories $[9,18]$.

\section{References}

1. Wu EY (2011) Juvenile idiopathic arthritis. Nelson Textbook of Pediatrics. (19thedn), Pa: Saunders Elsevier, Philadelphia, USA.

2. Lovell DJ (2008) Juvenile Idiopathic Arthritis: Clinical Features. Primer on the Rheumatic Diseases. (13thedn), Springer Science, New York

3. Yazici Y, Kautiainen H, Sokka T, Pincus T (2004) Morning stiffness in patients with early rheumatoid arthritis is associated more strongly with functional disability than with joint swelling and erythrocyte sedimentation rate. J Rheumatol 31: 1723-1726.

4. Patberg WR, Rasker JJ (2004) Weather effects in rheumatoid arthritis: from controversy to consensus. A review. J Rheumatol 31: 1327-1334.

5. Prakken B, Albani S, Martini A (2011) Juvenile idiopathic arthritis. Lancet 377 : 2138-2149.

6. Martini A, Lovell DJ (2010) Juvenile idiopathic arthritis: state of the art and future perspectives. Ann Rheum Dis 69: 1260-1263.

7. Berkun Y, Padeh S (2010) Environmental factors and the geoepidemiology of juvenile idiopathic arthritis. Autoimmun Rev 9: A319-324.

8. Jing-Long Huang, MD (2012) New Advances in Juvenile Idiopathic Arthritis Chang Gung Med J 35: 1-14.

9. Petty RE, Southwood TR, Manners P, Baum J, Glass DN, et al. (2004) International League of Associations for Rheumatology Classification of Juvenile Idiopathic Arthritis: Second Revision, Edmonton, 2001. J Rheumatol 31: 390-392.

10. Schneider R, Laxer RM (2012) Systemic Juvenile Idiopathic Arthritis. The Rheumatologist.

11. Johnson K, Gardner-Medwin J (2002) Childhood arthritis: classification and radiology. Clin Radiol 57: 47-58.

12. Cassidy JT, Petty RE (2005) Systemic arthritis. Textbook of pediatric rheumatology. (5thedn), Philadelphia: WB Saunders.

13. Hill J, Cairns E, Bell DA (2004) The joy of citrulline: new insights into the diagnosis, pathogenesis, and treatment of rheumatoid arthritis. J Rheumato 31: $1471-1473$.

14. Selvaag AM, Flato B, Dale K, Lien G, Vinje O, et al. (2006) Radiographic and clinical outcome in early juvenile rheumatoid arthritis and juvenile spondyloarthropathy: a 3-year prospective study. J Rheumatol 33: 1382-1391.

15. Hanson V, Kornreich HK, Bernstein B (2009) Subtypes of juvenile rheumatoid arthritis (correlations of age at onset, sex, and serologic factors). Arthritis Rheum 48: 184.

16. Magni-Manzoni S, Ruperto N, Pistorio A, Sala E, Solari N, et al. (2008) Development and validation of a preliminary definition of minimal disease activity in patients with juvenile idiopathic arthritis. Arthritis Rheum 59: 11201127.

17. Smolen JS, Landewe R, Breedveld FC, DougadosM, Emery P, et al. (2010) EULAR recommendations for the management of rheumatoid arthritis with synthetic and biological disease-modifying antirheumatic drugs. Ann Rheum Dis 69: 964-975.

18. Jensen T, Klarlund M, Hansen M, Jensen KE, Skjødt H, et al (2004) Connective tissue metabolism in patients with unclassified polyarthritis and early rheumatoid arthritis. Relationship to disease activity, bone mineral density, and radiographic outcome. J Rheumatol 31: 1698-1708. 